\title{
The economic value of organic dairy farms in Vermont and Minnesota
}

\author{
J. K. O'Hara*1 and R. L. Parsons† \\ ${ }^{*}$ Food \& Environment Program, Union of Concerned Scientists, Washington, DC 20006 \\ †Department of Community Development and Applied Economics, 204A Morrill Hall, University of Vermont, Burlington 05405
}

\section{ABSTRACT}

This study quantifies the overall economic values of organic dairy farms in Vermont and Minnesota and estimates the economic impacts of organic dairy farm sales relative to an equivalent level of sales from conventional dairy farms in those states. This question is of interest because the development of the organic dairy sector has allowed some farms that likely would not have remained in the conventional dairy business to continue being economically viable as organic dairy farms. Thus, these sales provide an economic impact in regions when this milk is exported to nonproducing regions. Organic and conventional dairy farm financial data in Vermont and Minnesota were collected and assembled to develop dairy farm production functions by region and dairy type. These production functions were then used in state-level input-output models to calculate economic impacts. The opportunity costs of organic dairy farm production were also estimated by comparing the relative statewide economic impacts of organic and conventional dairy farms if both experience a hypothetical 5-million-dollar increase in sales. Between 2008 and 2010, Vermont's 180 organic dairy farms annually contributed $\$ 76.3$ million in output (the value of an industry's production within the state), 808 jobs, $\$ 34.1$ million in gross state product, and $\$ 26.3$ million in labor income to Vermont's economy. Between 2009 and 2011, Minnesota's 114 organic dairy farms annually contributed $\$ 77.7$ million in output, 552 jobs, $\$ 32.1$ million in gross state product, and \$21 million in labor income to Minnesota's economy. In Vermont, organic dairy farm sales revenue would result in greater state-wide impacts of $3 \%$ in output, $39 \%$ in labor income, $33 \%$ in gross state product, and $46 \%$ in employment relative to the impacts from an equivalent level of sales revenue to conventional dairy farms. In Minnesota, these economic impacts are 4, 9, 11 , and $12 \%$ greater, respectively, for organic dairy farms relative to conventional dairy farms. This study concludes that organic

Received February 4, 2013.

Accepted May 27, 2013.

${ }^{1}$ Corresponding author: johara@ucsusa.org dairy farms may contribute more to the local economy than average and similar-size conventional dairy farms in the Northeast and Upper Midwest and that organic dairy farm milk production supports economic development in rural communities.

Key words: organic dairy farm, economic development, input-output model

\section{INTRODUCTION}

\section{Organic Milk Sector Background}

In recent decades, dairies in the United States have become larger, fewer in number, more productive, and are increasingly operated as confinement systems. In 2009 , there were 65,000 dairies in the United States, which is just $10 \%$ of the number of dairies that existed in 1970 (MacDonald et al., 2007; USDA NASS, 2010). The average herd size increased from 19 cows to 142 cows during this time period, and $31 \%$ of milk production now occurs on dairies with at least 2,000 cows (MacDonald et al., 2007; USDA NASS, 2010). Contributing factors to this trend include scale economies arising on larger dairies and inefficient operation of smaller dairies (Tauer and Mishra, 2006; Mosheim and Knox Lovell, 2009). For example, scale economies can occur on confinement dairy farms when installing capital equipment, such as a feed delivery or milking system, and housing structures (MacDonald and McBride, 2009). Although scale economies also exist on pasture-based dairies (Mayen et al., 2010), a limiting factor that does not apply to confinement dairy farms is that grazing land is constrained to be within proximity of the milking center.

As the dairy sector transformed, some consumers retained a preference for milk from traditional pasturebased dairies for a variety of reasons, including concern regarding the use of recombinant bovine somatotropin in conventional dairy production (Saucier and Parsons, accepted). The demand for this milk led to the formal development of the organic milk sector. In contrast to conventional dairy production, US Department of Agriculture regulations require that organic dairy cows obtain $30 \%$ of their food on a DM basis from pasture during the grazing season (the grazing season must be 
Table 1. Organic milk sales (2011) from cows: Top 10 states $^{1}$

\begin{tabular}{lcccrc}
\hline State & $\begin{array}{c}\text { 2011 Sales } \\
\text { (USD) }\end{array}$ & $\begin{array}{c}\text { 2011 Farms } \\
\text { (no.) }\end{array}$ & $\begin{array}{c}\text { Cows } \\
\text { (no.; December 31, } \\
2011)\end{array}$ & $\begin{array}{c}\text { Average } \\
\text { herd size }\end{array}$ & $\begin{array}{c}\text { 2011 Conventional } \\
\text { production rank }\end{array}$ \\
\hline California & $127,201,275$ & 72 & 32,939 & 457 & 1 \\
Texas & $120,232,218$ & 8 & 26,225 & 3,278 & 6 \\
Wisconsin & $82,278,236$ & 397 & 23,115 & 58 & 2 \\
Oregon & $69,140,278$ & 43 & 16,256 & 378 & 18 \\
New York & $60,165,502$ & 235 & 17,471 & 74 & 5 \\
Pennsylvania & $42,632,437$ & 236 & 11,996 & 51 & 7 \\
Vermont & $41,702,950$ & 180 & 11,813 & 66 & 7 \\
Minnesota & $33,187,033$ & 114 & 9,381 & 82 & 10 \\
Washington & $25,628,798$ & 35 & 6,570 & 328 & 3 \\
Idaho & $25,310,940$ & 17 & 5,580 & 110 & \\
National total & $764,685,911$ & 1,823 & 199,737 & & \\
\hline
\end{tabular}

${ }^{1}$ Sources: USDA NASS (2012) and USDA ERS (2012a).

a minimum of $120 \mathrm{~d}$ ), consume only certified organic feed, not receive any artificial hormones, and only receive homeopathic or natural treatments for health disorders (USDA AMS, 2010). In 2011, 1,823 organic dairy farms existed nationally with farm sales equal to $\$ 765$ million (Table 1).

Most organic dairy farms were originally conventional dairy farms that transitioned to organic due to higher milk prices and greater price stability afforded through contract prices, a conversion that was relatively easy for dairies with cows already on pasture-based diets. These dairies may not have expanded to compete in the conventional milk market due to the existence of streams or valleys that constrained farm size, an inability to obtain the financing necessary to expand, or a lack of desire to operate a larger dairy if confinement systems were incompatible with their expertise or ethical values (Parsons, 2010; Saucier and Parsons, 2013).

\section{Organic Milk Production and Economic Development}

Whereas the disappearance of hundreds of thousands of small dairies has had adverse economic consequences in rural regions where they were once prominent, the development of the organic milk market helped preserve agricultural production and has contributed to the economy in regions where dairies would otherwise have ceased operations. Many organic dairy farmers in Vermont believe they would no longer be in business as a conventional dairy if they had not converted (Parsons, 2010).

Although economic impact studies have been conducted of the conventional dairy sector (Deller, 2007; Neibergs and Holland, 2007; Cabrera et al., 2008; Connecticut Department of Economic and Community Development and the Department of Agriculture, 2009), few studies have examined either the economic value of organic dairy farms or compared the relative economic impacts of conventional and organic dairy farm production systems. The objective of the study is to answer 2 specific questions that address these issues. First, the study quantifies the overall economic values of organic dairy farms within 2 states examined as case studies: Vermont and Minnesota. Second, the study compares economic impacts of organic dairy farm sales relative to an equivalent level of sales from conventional dairy farms. The study is conceptually similar to studies that evaluated the relative economic impacts of organic and conventional crop production (Mon and Holland, 2006; Swenson et al., 2007).

According to export base theory, exports can increase regional economic activity by a multiple of the initial level of sales due to the direct sales of the exporting sector and sales of non-exporting sectors in the region that sell intermediate inputs to the exporting sector (Shaffer et al., 2004). Thus, maintaining or increasing organic milk production provides net economic impacts in a region if the farms produce milk in excess of what their region's population can consume. This is a reasonable assumption in this study. If average per capita milk consumption in Vermont and Minnesota, the 2 states this study examines, is the same as the national average and residents only consume milk produced within their state, their residents would only be capable of consuming 14 and $33 \%$, respectively, of the total milk produced in their state. This implies that the overall economic values calculated to address the first question can be interpreted as the net economic impacts of the organic sector if it is hypothesized that the dairies would no longer be in business if they had not converted.

The second question compares the net regional economic impacts if the organic dairy farms were to have remained as conventional dairy farms if they had not converted. The relative impacts of these 2 distinct dairy farm production systems depend upon the relative utilization of purchased inputs, such as feed, and primary 
factors of production, such as labor and capital, and the extent to which they are regionally sourced. Organic dairies pay more for feed on a per-unit basis than conventional dairies because certified organic feeds command higher market prices and, because organic dairy farms typically have smaller herds, they generally purchase feed in smaller quantities. Whereas cows on conventional dairy farms generally receive a greater percentage of DM from grain and protein meal, organic dairies tend to produce less milk per cow and feed their cows less concentrate DM. Nonetheless, some organic dairy farms earn more revenue per cow than conventional dairy farms because they sell milk for a higher per-unit price.

\section{MATERIALS AND METHODS}

\section{Data Sources}

Financial data on conventional and organic dairy farms in both Vermont and Minnesota was obtained to develop dairy production functions that are specific to those states and dairy types. Vermont and Minnesota are examined as case studies for several reasons. First, these states represent the 2 regions - Northeast and Upper Midwest - where $70 \%$ of organic dairies were located in 2011 (USDA NASS, 2012). Economic impacts in distinct regions are calculated due to regional variation in management practices. Organic and conventional dairy farms in both regions generally produce most of their forage needs. However, the shorter growing season in Vermont requires that most organic and conventional dairy farms purchase almost all of their concentrate, whereas Minnesota organic and conventional dairy farms tend to grow most of their grain and supplement nutritional needs by purchasing protein. Second, the organic dairy sector is prominent in both states. Table 1, which shows the top 10 organic milk-producing states in the United States, shows that Vermont ranks seventh nationally in farm sales of organic milk and fourth in the number of organic dairy farms, whereas Minnesota is eighth and fifth, respectively. In 2011, $8 \%$ of Vermont's milk sales - the second-highest percentage among major dairy-producing states - as well as 3\% of Minnesota's milk sales were organic (USDA ERS, 2012b). Finally, Vermont and Minnesota are examined because financial data are available for both the organic and conventional dairy sectors in both states over a multi-year period. Although organic milk production is also prominent in the West, the results may not be representative of that region because those organic dairy farms have larger herd sizes and more productive cows than in the Northeast and Upper Midwest.
Financial data on Vermont's organic dairy farms was obtained through primary data collection via an annual survey (Parsons and McCrory, 2011). Financial data on Minnesota's dairy farms was accessed from the Farm Financial Database (FINBIN, 2012) maintained by the University of Minnesota Center for Farm Financial Management (St. Paul) and financial data for New England conventional dairy farms was accessed from the annual Northeast Dairy Farm Summary (NDFS), a joint project of Farm Credit East (Enfield, CT), Farm Credit of Maine (Auburn, ME), and Yankee Farm Credit (Williston, VT; Samuelson, 2009, 2010; Lidback, 2011). Selection bias in the samples is possible as only dairies that are capable of documenting financial data can be included, which could be correlated with dairies with relatively greater financial performance. The Vermont organic dairy farm data are perhaps a more representative sample of organic dairies than the New England conventional dairy data are of conventional dairies, as many dairies in the NDFS sample are Farm Credit customers and NDFS excludes dairies from the sample with herd health or business disruptions (Lidback and Laughton, 2012).

Financial data on New England conventional dairies were used to represent Vermont conventional dairy farms because NDFS does not separately report financial data for conventional dairies in Vermont. This data are a reasonable proxy for Vermont, as $63 \%$ of New England's 2011 milk production occurred in Vermont (USDA ERS, 2012a). Northeast Dairy Farm Summary aggregates New York and New England dairies when reporting the financial performance of small conventional dairies, and New York dairies have relatively lower feed expenses and higher crop sales than dairies in New England (Lidback and Laughton, 2012). To develop parameter values more representative of small conventional dairy farms in Vermont, a crop sales estimate was derived by assuming that the NDFS-reported small conventional dairy crop sales estimate equaled the weighted sum of crop sales for New York and New England small dairy farms, where the weights equaled the number of respective dairy farms in the sample. To make the calculation, it was assumed that the ratio of crop sales between New York and New England dairies of all sizes was the same as the corresponding ratio for small conventional dairies. An identical procedure was followed for feed costs.

The financial data reported by the 3 different data sources was standardized to develop average annual per-cow estimates of revenues and expenses for both organic and conventional dairy production systems in Vermont and Minnesota (Tables 2 and 3). Off-farm income was excluded. A 3-yr average of the most recent 
data in these 2 states was used because of volatile market conditions. These data are from 2009 through 2011 in Minnesota and from 2008 through 2010 in Vermont. Both the conventional and organic dairy farm sectors will likely experience a worse financial year in 2012 relative to the immediately preceding years due to higher feed prices, so the results could overstate the current economic value of these sectors. In addition, the data for each state include 2009, a financially challenging year for organic and conventional dairy farms. Other dairy economic impact studies have also used average values of data from multiple years because of market volatility (Deller, 2007). Three years was selected because dairy market conditions are sometimes referred to move through a 3-yr cycle (Wolf, 2010; Lidback and Laughton, 2012).

Vermont organic and Minnesota dairy farm data are available on the number of hours worked but not on the number of employees. To arrive at employment estimates for those dairy farms, total paid and unpaid hours worked was converted into full-time-equivalent job estimates by dividing by 2,964 , which is the average annual number of hours worked reported in the NDFS survey sample. The number of full-time equivalent workers was then divided by the percentage of full-time-equivalent jobs in the dairy sector, which is 0.85 (MIG, 2012). The on-farm employment estimates do not distinguish between immigrant labor, which is more prevalent on larger dairies, and US-born labor. The methodology is likely to overstate the economic effects of wage increases on larger conventional dairies to the extent they are more dependent on immigrant labor, as it does not account for reduced local spending that would occur from employee remittance payments.

\section{Input-Output Modeling}

Input-output (I-O) modeling was conducted to estimate the economic value of organic dairy farms in

Table 2. Financial performance of Vermont (VT) and Northeast dairy sector (NE; average values from 2008 to 2010$)^{1}$

\begin{tabular}{|c|c|c|c|}
\hline \multirow[b]{2}{*}{ Item } & \multicolumn{3}{|c|}{ Dairy farm } \\
\hline & NE conventional & VT organic & $\begin{array}{c}\text { NE and New York } \\
\text { conventional } \\
(89 \text { cows or less })\end{array}$ \\
\hline Average no. of cows/dairy & 287 & 63 & 66 \\
\hline Average no. of dairies & 135 & 33 & 129 \\
\hline \multicolumn{4}{|l|}{ Average per-cow production } \\
\hline $\mathrm{kg} / \mathrm{yr}$ & 9,874 & 5,967 & 8,861 \\
\hline $\mathrm{lb} / \mathrm{yr}$ & 21,769 & 13,154 & 19,535 \\
\hline \multicolumn{4}{|l|}{ Revenue (\$/cow per year) } \\
\hline Milk sales & 3,800 & 4,046 & 3,277 \\
\hline Cattle/cow/calf sales & 181 & 177 & 209 \\
\hline Crop sales & 143 & 28 & 181 \\
\hline Inventory and transfer adjustments & 50 & 83 & 4 \\
\hline Other & 323 & 229 & 279 \\
\hline Total farm revenue $(\$ /$ cow per year $)$ & 4,497 & 4,563 & 3,950 \\
\hline \multicolumn{4}{|l|}{ Operating expenses ( $\$ /$ cow per year) } \\
\hline Chemicals and sprays & 39 & 1 & 45 \\
\hline Custom hire & 154 & 160 & 73 \\
\hline Feed & 1,423 & 1,190 & 1,111 \\
\hline Fertilizer and lime & 145 & 37 & 144 \\
\hline Freight and trucking (marketing) & 223 & 92 & 208 \\
\hline Gasoline, fuel, and oil & 197 & 144 & 190 \\
\hline Insurance & 71 & 82 & 75 \\
\hline Interest & 130 & 155 & 138 \\
\hline Labor & 647 & 359 & 284 \\
\hline Rent & 77 & 73 & 51 \\
\hline Repairs & 251 & 277 & 259 \\
\hline Seed and plants & 53 & 25 & 85 \\
\hline Supplies & 260 & 241 & 216 \\
\hline Taxes (real estate) & 47 & 52 & 100 \\
\hline Utilities & 110 & 138 & 137 \\
\hline Veterinary, medicine, breeding & 140 & 100 & 110 \\
\hline Other & 120 & 169 & 123 \\
\hline Cow replacements & 25 & 0 & 15 \\
\hline Depreciation & 266 & 446 & 431 \\
\hline Total farm expenses $(\$ /$ cow per year $)$ & 4,377 & 3,741 & 3,795 \\
\hline Net farm revenue $(\$ /$ cow per year $)$ & 120 & 822 & 154 \\
\hline
\end{tabular}

${ }^{1}$ Sources: Samuelson (2009, 2010), Lidback (2011), and Parsons and McCrory (2011). 
Table 3. Financial performance of the Minnesota dairy sector (average values from 2009 to 2011) ${ }^{1}$

\begin{tabular}{|c|c|c|c|}
\hline \multirow[b]{2}{*}{ Item } & \multicolumn{3}{|c|}{ Dairy farm } \\
\hline & Conventional & Organic & $\begin{array}{c}\text { Conventional } \\
\text { (200 cows or less) }\end{array}$ \\
\hline Average no. of cows/dairy & 148 & 80 & 84 \\
\hline Average no. of dairies & 469 & 32 & 379 \\
\hline \multicolumn{4}{|l|}{ Average per-cow production } \\
\hline $\mathrm{kg} / \mathrm{yr}$ & 9,998 & 5,624 & 8,992 \\
\hline $\mathrm{lb} / \mathrm{cow}$ & 22,041 & 12,399 & 19,823 \\
\hline \multicolumn{4}{|l|}{ Revenue (\$/cow per year) } \\
\hline Milk sales & 3,605 & 3,160 & 3,198 \\
\hline Cattle/cow/calf sales & 151 & 135 & 201 \\
\hline Crop sales & 483 & 93 & 417 \\
\hline Total inventory change & 197 & 129 & 102 \\
\hline Other & 520 & 251 & 314 \\
\hline Total farm revenue (\$/cow per year) & 4,955 & 3,767 & 4,232 \\
\hline \multicolumn{4}{|l|}{ Operating expenses ( $\$ /$ cow per year) } \\
\hline Chemicals and sprays & 56 & 3 & 71 \\
\hline Custom hire & 153 & 152 & 141 \\
\hline Feed & 1,182 & 608 & 1,069 \\
\hline Fertilizer and lime & 144 & 133 & 189 \\
\hline Freight and trucking (marketing) & 101 & 97 & 109 \\
\hline Gasoline, fuel, and oil & 194 & 193 & 205 \\
\hline Insurance & 86 & 69 & 101 \\
\hline Interest & 222 & 230 & 257 \\
\hline Labor & 440 & 368 & 252 \\
\hline Rent & 257 & 306 & 223 \\
\hline Repairs & 271 & 335 & 300 \\
\hline Seed and plants & 139 & 101 & 175 \\
\hline Supplies & 129 & 119 & 131 \\
\hline Taxes (real estate) & 29 & 38 & 39 \\
\hline Utilities & 113 & 106 & 138 \\
\hline Veterinary, medicine, breeding & 176 & 62 & 162 \\
\hline Other & 353 & 214 & 274 \\
\hline Cow replacements & 12 & 4 & 22 \\
\hline Depreciation & 262 & 238 & 290 \\
\hline Total farm expenses ( $\$ /$ cow per year) & 4,318 & 3,378 & 4,150 \\
\hline Net farm revenue (\$/cow per year) & 637 & 389 & 82 \\
\hline
\end{tabular}

${ }^{1}$ Source: FINBIN (2012).

Vermont and Minnesota using the production functions that are developed. Input-output models estimate how sales in one particular industry affect a region's output, labor income, employment, and gross regional product, based on statistical relationships between sectors in an economy. This study estimates farm-level economic values and does not quantify the economic values from any downstream sectors in the organic milk supply chain, such as from organic milk processing or retail sales. Input-output models are fixed-price models, implying that an expansion that occurs in one sector does not affect the relative prices of any sectors within the economy. Input-output models are more accurate when considering smaller hypothetical increases in production because they do not incorporate resource constraints for inputs and assume that sectors exhibit constant returns to scale.

Vermont and Minnesota I-O 2010 state-level databases developed by IMPLAN (MIG Inc., 2010) are used to estimate economic impacts. IMPLAN compiles, estimates, and interpolates data from a variety of sources, including the US Department of Agriculture, Bureau of Economic Analysis, Bureau of Labor Statistics, and US Census Bureau, to construct a database of economic relationships in the economy. Although IMPLAN is one of the most-utilized I-O modeling systems, it can be inaccurate when the disparate data sources are updated at frequencies and geographical scales that do not apply to the region and sectors under consideration.

Results from I-O models are divided into 3 categories. The direct effects are the economic impacts associated from the sales to the sector under examination - in this case, organic dairy farms. The induced effects are the economic impacts resulting from an increase in labor incomes of employees and proprietors in that industry. The indirect effects are the economic impacts associated with the increase in sales from industries that sell inputs to the industry under consideration. The results are presented with multipliers, which are ratios of the total economic impacts within a region relative to the economic impacts of the industry being studied (Miller and Blair, 2009). 
The proxy dairy production function of IMPLAN was replaced with conventional and organic dairy farm production functions specific to Vermont and Minnesota to estimate economic impacts. As the linkages between conventional and organic dairy farms and the rest of the economy are treated as the same in these 2 states, this implicitly assumes that organic and conventional dairy farms in these 2 states have the same supply chain.

The procedures in Mon and Holland (2006) were followed to convert standardized financial accounting tables into I-O production functions. Total dairy farm outlays were categorized into purchased inputs, such as feed and utilities, and value-added primary factors of production. The operating expenses reported in Tables 2 and 3 were then allocated among IMPLAN input expense categories. In instances where IMPLAN industry definitions were more specific than the reported accounting data, expenditures were allocated across these categories proportionally using IMPLAN proxy industry spending patterns. Because IMPLAN requires that prices be converted from purchaser prices to producer prices, expenditures were allocated for each input among the producing, wholesale, retail, and transportation service sectors by a proportion determined by IMPLAN's standard margining coefficients. Input expenditures were then multiplied by IMPLAN's local purchase percentage for each input to develop state-specific results.

Revenue from milk sales, cow/calf sales, crop sales, and inventory adjustments were included in the economic impact calculations, as expenses were incurred to support revenue from all of these sources. The impacts of "other" revenue are excluded, as government payments comprise a significant component of this category. Total organic milk farm sales revenue reported in Table 1 for Vermont and Minnesota were used as state-wide farm milk sales revenue. To determine statewide organic dairy farm non-milk sales revenue, the state-level organic milk sales reported in Table 1 was divided by the ratio of milk sales to total dairy revenue (excluding "other" revenue) that is reported in Tables 2 and 3. This assumes that milk sales comprised the same proportion of total revenue for organic dairy farms not in the sample as it did for organic dairies included in the sample.

\section{RESULTS AND DISCUSSION}

\section{Dairy Farm Financial Data}

This study compared the relative economic impacts of conventional and organic dairy farms of average size, as well as organic dairy farms and conventional dairy farms of similar size. This is because many or- ganic dairy farms maintained the same approximate herd size when they converted from conventional dairy production and production practices for conventional dairy farms may vary systematically by size. Herd size cutoffs for small conventional dairies were selected in both states so that the average herd size of the conventional dairy sample was close to the average herd size of the organic dairy sample. Because many organic dairy farms were originally conventional dairy farms, it is reasonable to assume that they have the same supply chain as conventional dairy farms. This is because they will continue to purchase some inputs, such as fuel and supplies, through the same channels that they had before converting. Also, in both regions, some feed suppliers carry both conventional and organic concentrates.

Table 2 shows that financial data in Vermont was, on average, collected from 33 organic dairies annually and available from 135 conventional dairies and 129 small conventional dairies. This implies the organic dairies in Vermont's sample account for approximately $18 \%$ of the state's organic dairies (Table 1). On average, organic dairies in Vermont have fewer cows than conventional dairies and produce less milk per cow. Table 2 shows that the average conventional dairy in New England from 2008 to 2010 had 287 cows with each cow producing $9,874 \mathrm{~kg}(21,769 \mathrm{lb})$ of milk annually. Organic dairies in Vermont, in contrast, had 63 cows, on average, with per cow milk production at $60 \%$ of conventional levels. Conventional dairies in the region of similar size to organic dairies (i.e., less than 89 cows) had 66 cows, on average, which each produced 8,861 $\mathrm{kg}(19,535 \mathrm{lb})$ of milk per year. The relative size and productivity of these 2 types of dairy farms in Vermont is consistent with national averages, although conventional dairy farms in the NDFS sample were larger and more productive than national averages of conventional dairy farms. Nationally, in 2010, on average, organic dairy farms had 77 cows that each produced 6,298 $\mathrm{kg}(13,885 \mathrm{lb})$ of milk per year, whereas conventional dairy farms had 182 cows that each produced 9,508 kg (20,962 lb) of milk per year (USDA ERS, 2012c,d).

In Vermont, organic dairies received $\$ 0.68 / \mathrm{kg}(\$ 0.31 /$ lb) for milk and conventional dairies received $\$ 0.37$ / $\mathrm{kg}(\$ 0.17 / \mathrm{lb})$. Even though organic cows produce less milk, Table 2 shows that higher prices imply that organic dairies in Vermont earned greater milk sales revenue per cow than conventional dairies. Purchased feed is the largest expense for dairy farms. At $\$ 1,190$ per cow, organic dairies in Vermont spent less on feed than conventional dairies within their region. Table 2 shows that at $\$ 822$ per cow, Vermont's organic dairy farms had greater average net farm revenue relative to both conventional ( $\$ 120$ per cow) and small conventional dairies (\$154 per cow). 
Table 3 shows that, in Minnesota, data was available from 469 conventional, 379 small conventional, and 32 organic dairies annually, on average. Minnesota's sample of organic dairy farms accounted for approximately $28 \%$ of the state's organic dairy farms (Table 1). Similar to Vermont, Table 3 shows that in Minnesota, organic dairy farms were smaller than the average conventional dairy farm with cows that produced less milk. On average, conventional dairies had 148 cows that each produced 9,998 $\mathrm{kg}(22,041 \mathrm{lb})$ of milk per year, whereas organic dairies had 80 cows that produced 5,624 kg (12,399 lb) of milk per cow annually. Minnesota's small conventional dairies (i.e., those with less than 200 cows) had 84 cows that each produced $8,992 \mathrm{~kg}(19,823 \mathrm{lb})$ of milk annually, on average.

In Minnesota, the price premium for organic milk was not as large as in Vermont, as organic prices were $\$ 0.55 / \mathrm{kg} \quad(\$ 0.25 / \mathrm{lb})$ relative to $\$ 0.35 / \mathrm{kg} \quad(\$ 0.16 / \mathrm{lb})$ for conventional milk. Thus, unlike Vermont, Table 3 shows that milk revenue per cow was greater for Minnesota conventional dairy farms. Organic dairy feed costs in Minnesota were $51 \%$ of Vermont organic dairy feed costs on a per-cow basis because Minnesota dairies grew more of their own feed. In Minnesota, on average, organic dairies spent $\$ 608$ per cow per year relative to $\$ 1,182$ per cow per year for conventional dairies.

Table 3 shows that average net farm revenue was $\$ 389$ per cow for Minnesota's organic sector. This is lower than $\$ 637$ per cow for the conventional sector, but greater than $\$ 82$ per cow for the small conventional sector. A critical reason for this disparity between the states is that non-milk revenue sources, such as crop sales and "other" sources of income that include government payments, are relatively greater for Minnesota conventional dairies than organic dairies. This difference in non-milk sales revenue between conventional and organic dairies is not as pronounced in Vermont. Operating expenses in Tables 2 and 3, however, do not include the opportunity cost of labor for the farm operators. This is because a farm operator that owns and operates a dairy farm typically will not pay themselves, or potentially other family members that work on the dairy, an hourly wage, and will instead retain the revenue that remains after the rest of the expenses are paid to support cost-of-living expenses for their family.

\section{Economic Value of Organic Dairy Farms}

Table 4 reports the economic values of organic dairy farms in Vermont and Minnesota. In Vermont, organic dairy farms contributed $\$ 76.3$ million in output to the state's economy with an output multiplier of 1.7. They also contributed $\$ 34.1$ million in gross state product with a multiplier of $2.3, \$ 26.3$ million in labor income with a multiplier of 1.8 , and 808 jobs with a multiplier of 1.7. In Minnesota, organic dairy farms contributed $\$ 77.7$ million in output to the state's economy with an output multiplier of $2.1, \$ 32.1$ million in gross state product with a multiplier of $3.9, \$ 21$ million in labor income with a multiplier of 2.7 , and 552 jobs with a multiplier of 2.2. Minnesota's organic dairy farms have greater multipliers than Vermont's organic dairy farms. Part of the reason for this difference is because a greater percentage of purchased concentrates are grown and processed within Minnesota's economy relative to Vermont's economy, as the short growing season in Vermont allows limited opportunity for grain production.

\section{Relative Economic Impacts of Conventional and Organic Dairy Farms}

The economic implications of expanding dairy farm revenue were estimated using a hypothetical $\$ 5$ million level of sales revenue for organic, conventional, and small conventional dairy farms. Assuming that farm revenue expands by the same level allows for relative comparisons of region-specific economic impacts. The relative economic impacts of organic and conventional dairy farms, and corresponding multipliers, will not change in I-O modeling regardless of the hypothetical sales level selected, although such hypothetical calculations have a greater degree of accuracy when they are for smaller amounts because land available for dairy production within these states is fixed. Revenue is the same metric used in other dairy economic impact assessments (Deller, 2007) and in studies that have compared the relative economic impacts of conventional and organic crop production (Mon and Holland, 2006). Examining the impacts of a revenue expansion by equivalent amounts in each sector implies that conventional dairies, which receive lower per-unit milk prices, will increase milk production by a relatively greater amount than organic dairies to attain the same level of revenue. Further, this level of sales revenue is modest relative to the overall size of the economy in both states. In 2011, Vermont's gross domestic product (GDP) was $\$ 26$ billion and Minnesota's GDP was $\$ 282$ billion (DOC BEA, 2012). This implies that the fixed-price assumption used in I-O modeling is reasonable for this level of sales.

Table 5 shows that $\$ 5$ million of additional organic dairy farm sales would increase Vermont's output by $3 \%$ greater than $\$ 5$ million in conventional dairy farm sales and by $2 \%$ greater than $\$ 5$ million in small conventional farm sales. Five million dollars in organic dairy farm revenue would increase Vermont's labor income by $39 \%$ greater than $\$ 5$ million in conventional dairy farm revenue and $41 \%$ greater than $\$ 5$ million in small conventional dairy farm revenue. The impacts on gross state 
Table 4. Economic value of the organic dairy sector in Vermont and Minnesota

\begin{tabular}{lcccc}
\hline Impact type & $\begin{array}{c}\text { Employment } \\
\text { (no. of jobs) }\end{array}$ & $\begin{array}{c}\text { Labor } \\
\text { Income }(\$ / \mathrm{yr})\end{array}$ & $\begin{array}{c}\text { Gross state } \\
\text { Product }(\$ / \mathrm{yr})\end{array}$ & Output $(\$ / \mathrm{yr})$ \\
\hline Vermont organic dairy & & & & \\
$\quad$ Direct effect & 474 & $14,400,239$ & $14,934,053$ & $44,666,833$ \\
Indirect effect & 182 & $6,212,105$ & $9,197,895$ & $15,389,517$ \\
Induced effect & 153 & $5,649,545$ & $9,994,042$ & $16,216,070$ \\
Total effect $_{\text {Multiplier }}^{1}$ & 808 & $26,261,889$ & $34,125,990$ & $76,272,420$ \\
Minnesota organic dairy $_{\text {Direct effect }}$ & 1.71 & 1.82 & 2.29 & 1.71 \\
Indirect effect & 253 & $7,818,257$ & $8,221,423$ & $36,926,826$ \\
Induced effect & 171 & $7,645,092$ & $13,911,915$ & $24,624,399$ \\
Total effect & 128 & $5,490,899$ & $9,926,523$ & $16,147,802$ \\
Multiplier & 552 & $20,954,248$ & $32,059,861$ & $77,699,026$ \\
& 2.18 & 2.68 & 3.90 & 2.10 \\
\hline
\end{tabular}

${ }^{1}$ Multiplier $=$ direct effect:total effect.

product in Vermont would be greater for the organic sector by 33 and $29 \%$ relative to the conventional and small conventional sectors, respectively. Employment economic impacts in Vermont would also be highest in the organic sector relative to the conventional and small conventional sectors by 46 and $18 \%$, respectively. Although the indirect effects of the conventional and small conventional sector are greater than organic dairies due to greater dependence on purchased inputs, the induced effects for the organic sector are sufficiently large that the total economic impacts are greater.

Just as with Vermont, Table 6 shows that an expansion of $\$ 5$ million in revenue for organic dairy farms would have greater economic impacts in Minnesota's economy relative to conventional or small conventional dairy farms. Also similar is that in Minnesota, organic dairy farms would have greater induced effects than conventional and small conventional dairy farms in all 4 categories. For the organic sector, such an expansion would lead to an increase of $4 \%$ in output, $9 \%$ in income, $11 \%$ in gross state product, and $12 \%$ in employment relative to the economic impacts that would occur in Minnesota's economy from conventional dairy farm sales. Relative to small conventional dairy farms, these increases are 3, 35, 26, and $4 \%$ greater, respectively. In both Vermont and Minnesota, organic dairy farms have greater output multipliers than conventional and small conventional dairy farms, with smaller employ-

Table 5. Economic impacts in Vermont of a $\$ 5$ million increase in revenue: comparison of organic, conventional, and small conventional dairy farms

\begin{tabular}{|c|c|c|c|c|}
\hline Item & $\begin{array}{l}\text { Employment } \\
\text { (no. of jobs) }\end{array}$ & $\begin{array}{c}\text { Labor } \\
\text { Income }(\$ / y r)\end{array}$ & $\begin{array}{c}\text { Gross state } \\
\text { Product }(\$ / y r)\end{array}$ & Output $(\$ / y r)$ \\
\hline \multicolumn{5}{|l|}{ Impact type } \\
\hline \multicolumn{5}{|l|}{ Organic } \\
\hline Direct effect & 53 & $1,612,160$ & $1,671,923$ & $5,000,000$ \\
\hline Indirect effect & 20 & 695,468 & $1,029,738$ & $1,722,913$ \\
\hline Induced effect & 17 & 632,487 & $1,118,870$ & $1,815,449$ \\
\hline Total effect & 90 & $2,940,116$ & $3,820,531$ & $8,538,362$ \\
\hline Multiplier $^{1}$ & 1.71 & 1.82 & 2.29 & 1.71 \\
\hline \multicolumn{5}{|l|}{ Conventional } \\
\hline Direct effect & 27 & 850,970 & 906,876 & $5,000,000$ \\
\hline Indirect effect & 23 & 809,196 & $1,159,426$ & $1,968,811$ \\
\hline Induced effect & 12 & 455,286 & 805,697 & $1,306,982$ \\
\hline Total effect & 62 & $2,115,452$ & $2,872,000$ & $8,275,794$ \\
\hline Multiplier & 2.34 & 2.49 & 3.17 & 1.66 \\
\hline \multicolumn{5}{|l|}{ Small conventional } \\
\hline Direct effect & 41 & 803,297 & 939,972 & $5,000,000$ \\
\hline Indirect effect & 23 & 838,151 & $1,231,193$ & $2,090,234$ \\
\hline Induced effect & 12 & 450,170 & 796,661 & $1,292,305$ \\
\hline Total effect & 77 & $2,091,618$ & $2,967,826$ & $8,382,539$ \\
\hline Multiplier & 1.86 & 2.60 & 3.16 & 1.68 \\
\hline \multicolumn{5}{|l|}{ Comparison of total effects (\%) } \\
\hline \multicolumn{5}{|l|}{ Sector comparison } \\
\hline Organic - conventional & 46 & 39 & 33 & 3 \\
\hline Organic - small conventional & 18 & 41 & 29 & 2 \\
\hline
\end{tabular}

${ }^{1}$ Multiplier $=$ direct effect:total effect. 
Table 6. Economic impacts in Minnesota of $\$ 5$ million increase in revenue - comparison of organic, conventional, and small conventional dairy farms

\begin{tabular}{|c|c|c|c|c|}
\hline Item & $\begin{array}{l}\text { Employment } \\
\text { (no. of jobs) }\end{array}$ & $\begin{array}{c}\text { Labor } \\
\text { Income }(\$ / y r)\end{array}$ & $\begin{array}{c}\text { Gross state } \\
\text { Product }(\$ / y r)\end{array}$ & Output $(\$ / y r)$ \\
\hline \multicolumn{5}{|l|}{ Impact type } \\
\hline \multicolumn{5}{|l|}{ Organic } \\
\hline Direct effect & 34 & $1,058,615$ & $1,113,205$ & $5,000,000$ \\
\hline Indirect effect & 23 & $1,035,168$ & $1,883,714$ & $3,334,215$ \\
\hline Induced effect & 17 & 743,484 & $1,344,080$ & $2,186,459$ \\
\hline Total effect & 75 & $2,837,266$ & $4,340,998$ & $10,520,674$ \\
\hline Multiplier $^{1}$ & 2.18 & 2.68 & 3.90 & 2.10 \\
\hline \multicolumn{5}{|l|}{ Conventional } \\
\hline Direct effect & 27 & 923,271 & 956,202 & $5,000,000$ \\
\hline Indirect effect & 24 & $1,005,668$ & $1,733,091$ & $3,134,680$ \\
\hline Induced effect & 16 & 685,155 & $1,238,701$ & $2,014,938$ \\
\hline Total effect & 67 & $2,614,094$ & $3,927,995$ & $10,149,619$ \\
\hline Multiplier & 2.47 & 2.83 & 4.11 & 2.03 \\
\hline \multicolumn{5}{|l|}{ Small conventional } \\
\hline Direct effect & 32 & 395,571 & 445,082 & $5,000,000$ \\
\hline Indirect effect & 27 & $1,156,900$ & $1,994,502$ & $3,620,493$ \\
\hline Induced effect & 13 & 551,965 & 998,081 & $1,623,282$ \\
\hline Total effect & 72 & $2,104,436$ & $3,437,665$ & $10,243,774$ \\
\hline Multiplier & 2.23 & 5.32 & 7.72 & 2.05 \\
\hline \multicolumn{5}{|l|}{ Comparison of total effects (\%) } \\
\hline \multicolumn{5}{|l|}{ Sector comparison } \\
\hline Organic - conventional & 12 & 9 & 11 & 4 \\
\hline Organic - small conventional & 4 & 35 & 26 & 3 \\
\hline
\end{tabular}

ment, income, and gross state product multipliers. The relative employment economic impacts between organic and conventional dairy farms in both states would not change if other estimates were used of the number of hours worked in a year, including the estimate used by Cornell University (Ithaca, NY) of $2,760 \mathrm{~h}$ or a standard 40 -h work week $(2,080 \mathrm{~h})$. In general, a greater number of hours worked translates into fewer jobs and a greater employment multiplier.

These findings have policy implications. Dairy policies, including subsidized risk management programs and milk marketing orders, are often premised on conventional dairy practices and the assumption that all dairies produce a homogeneous product. However, organic dairy farms have a production function that differs than those of conventional dairy farms and they produce milk that is perceived by some consumers as differentiated. The results of this study imply that policymakers that prioritize rural economic development should be cognizant of different production practices and their relative regional economic impacts in the development of dairy programs, which will influence the future viability of organic dairy farms. Also, this study provides economic development agencies with evidence that justifies policies that promote organic dairy farms as a viable alternative to conventional production and, possibly more important, that transitioning to organic production maintains a critical export-based producing sector that increases regional economic activity relative to conventional production.

\section{CONCLUSIONS}

Organic dairy farming provides an opportunity for smaller conventional dairy farms to remain economically viable, which contributes to the local economy by preserving small farms in instances where large-scale conventional dairy production is impractical. This study shows that, in Vermont and Minnesota, the net economic impacts are positive if organic milk production occurs in lieu of conventional milk production. This result is influenced by the relatively greater induced effects of organic dairies, which occurs because they have relatively greater returns to labor for a given level of sales than conventional dairy farms. The study further finds that the economic multipliers of organic dairy farms are greater in Minnesota than in Vermont. This result occurs, in part, because a greater percentage of purchased concentrates are grown and processed within Minnesota's economy due to the shorter growing season in Vermont.

\section{REFERENCES}

Cabrera, V. E., R. Hagevoort, D. Solís, R. Kirksey, and J. A. Diemer. 2008. Economic impact of milk production in the state of New Mexico. J. Dairy Sci. 91:2144-2150.

Connecticut Department of Economic and Community Development and the Department of Agriculture. 2009. The Economic and Fiscal Impacts of Connecticut's Dairy Industry. Connecticut Department of Economic and Community Development and the Department of Agriculture, Hartford, CT.

Deller, S. C. 2007. The economic impact of milk production on the Wisconsin economy. Department of Agricultural and Applied Economics, Univ. Wisconsin, Madison. 
DOC BEA (Department of Commerce, Bureau of Economic Analysis). 2012. Regional economic accounts. Accessed Aug. 31, 2012 http://www.bea.gov/regional/index.htm.

FINBIN (Farm Financial Database). 2012. University of Minnesota Center for Farm Financial Management. Accessed Sep. 10, 2012. http://www.finbin.umn.edu/.

Lidback, J. 2011. 2010 Northeast dairy farm summary. Farm Credit East, Agricultural Credit Association (ACA), Enfield, CT; Farm Credit of Maine, ACA, Auburn, ME; and Yankee Farm Credit, ACA, Williston, VT.

Lidback, J., and C. Laughton. 2012. 2011 Northeast dairy farm summary. Farm Credit East, Agricultural Credit Association (ACA), Enfield, CT; Farm Credit of Maine, ACA, Auburn, ME; and Yankee Farm Credit, ACA, Williston, VT.

MacDonald, J. M., and W. D. McBride. 2009. The transformation of U.S. livestock agriculture: Scale, efficiency, and risks. US Department of Agriculture Economic Research Service, Washington, DC

MacDonald, J. M., E. J. O'Donoghue, W. D. McBride, R. F. Nehring, C. L. Sandretto, and R. Mosheim. 2007. Profits, Costs, and the Changing Structure of Dairy Farming. US Department of Agriculture Economic Research Service, Washington, DC.

Mayen, C. D., J. V. Balagtas, and C. E. Alexander. 2010. Technology adoption and technical efficiency: Organic and conventional dairy farms in the United States. Am. J. Agric. Econ. 92:181-195.

MIG Inc. 2010. 2010 IMPLAN state level data. Accessed Dec. 21, 2012. http://implan.com/V4/index.php?option=com virtuemart\&page $=$ shop.browse\&category_id $=900 \&$ Itemid $=13$.

MIG Inc. 2012. IMPLAN to FTE Conversions. Accessed May 30, 2012. http://implan.com/V4/index.php?option=com_multicategories\& view $=$ article $\& i d=628: 628 \&$ Itemid $=10$.

Miller, R. E., and P. D. Blair. 2009. Input-Output Analysis: Foundations and Extensions. 2nd ed. Cambridge University Press, New York, NY

Mon, P. N., and D. W. Holland. 2006. Organic apple production in Washington State: An input-output analysis. Renew. Agric. Food Syst. 21:134-141.

Mosheim, R., and C. A. Knox Lovell. 2009. Scale economies and inefficiency of U.S. dairy farms. Am. J. Agric. Econ. 91:777-794.

Neibergs, J. S., and D. Holland. 2007. Economic impact of Washington dairy farms: An input-output analysis. School of Economic Sciences, Washington State University Extension, Pullman.

Parsons, B. 2010. Vermont's dairy sector: Is there a sustainable future for the $800 \mathrm{lb}$. gorilla? University of Vermont Center for Rural Studies, Burlington.

Parsons, B., and L. McCrory. 2011. Study finds declining profitability of Vermont organic dairy farms from 2006-2010. Accessed Jun. 21 , 2013. http://www.nodpa.com/production_economics_parsons_declining_profitability_111311.shtml.

Samuelson, J. 2009. 2008 Northeast dairy farm summary. Farm Credit of Maine, Agricultural Credit Association (ACA), Auburn, ME;
Farm Credit of Western New York, ACA, Batavia, NY; First Pioneer Farm Credit, ACA, Enfield, CT; and Yankee Farm Credit, ACA, Williston, VT.

Samuelson, J. 2010. 2009 Northeast dairy farm summary. Farm Credit East, Agricultural Credit Association (ACA), Enfield, CT; Farm Credit of Maine, ACA, Auburn, ME; and Yankee Farm Credit, ACA, Williston, VT.

Saucier, O., and R. Parsons. Refusing to 'push the cows': The rise of organic dairying in the Northeast and Midwest. Agric. Hist. (accepted).

Shaffer, R., S. Deller, and D. Marcouiller. 2004. Community Economics: Linking Theory and Practice. 2nd ed. Blackwell Publishing, Ames, IA.

Swenson, D., L. Eathington, and C. Chase. 2007. Determining the methods for measuring the economic and fiscal impacts associated with organic crop conversion in Iowa. Leopold Center for Sustainable Agriculture, Iowa State Univ., Ames.

Tauer, L. W., and A. K. Mishra. 2006. Can the small dairy farm remain competitive in US agriculture? Food Policy 31:458-468.

USDA AMS (US Department of Agriculture Agricultural Marketing Service). 2010. National organic program pasture rulemaking. Accessed June 27, 2012. http://www.ams.usda.gov/AMSv1.0/ nopaccesstopasture.

USDA ERS (US Department of Agriculture Economic Research Service). 2012a. Milk cows and production by state and region, 2008-2012 (cont.). Accessed Oct. 9, 2012. http://www.ers.usda. gov/datafiles/Dairy_Data/milkcowsandprod_1_.xls.

USDA ERS (US Department of Agriculture Economic Research Service). $2012 \mathrm{~b}$. Milk production costs and returns per hundredweight (cwt) sold, by state, 2011. Accessed June 22, 2012. http://www.ers. usda.gov/Data/CostsAndReturns/TestPick.htm\#milkproduction.

USDA ERS (US Department of Agriculture Economic Research Service). 2012c. Organic milk production costs and returns per hundredweight (cwt) sold, by state, 2010. Accessed Aug. 23, 2012. http://www.ers.usda.gov/data-products/commodity-costs-andreturns/features.aspx.

USDA ERS (US Department of Agriculture Economic Research Service). 2012d. Conventional milk production costs and returns per hundredweight (cwt) sold, by state, 2010. Accessed Aug. 23, 2012. http://www.ers.usda.gov/data-products/commodity-costs-andreturns/features.aspx.

USDA NASS (US Department of Agriculture, National Agricultural Statistics Service). 2010. Overview of the United States dairy industry. Accessed July 3, 2012. http://usda.mannlib.cornell.edu/ usda/current/USDairyIndus/USDairyIndus-09-22-2010.pdf.

USDA NASS (US Department of Agriculture, National Agricultural Statistics Service). 2012. 2011 Certified Organic Production Survey. USDA NASS, Washington, DC.

Wolf, C. 2010. The next peak milk price. Michigan Dairy Review $15: 14$. 